\title{
Pediatric Craniofacial Surgery: State of the Craft
}

Editor

EDWARD P. BUCHANAN

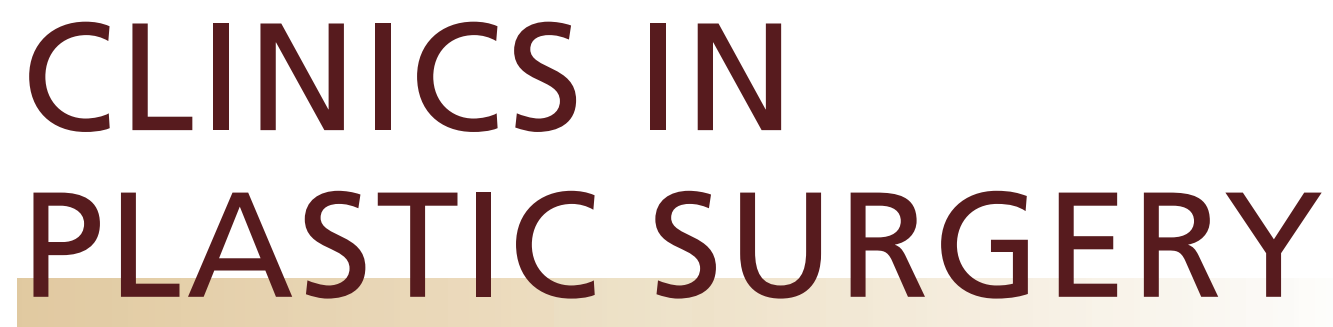

www.plasticsurgery.theclinics.com

April 2019 • Volume 46 - Number 2 